\title{
A synergistic of pectinase, cellulase, and glucoamylase on anthocyanin content and extraction yield of roselle petals (Hibiscus sabdariffa L.)
}

\author{
Mardiah ${ }^{1 *}$, Noli Novidahlia' ${ }^{1}$, Ma'rifat Khoirunnisa' ${ }^{1}$, Hanafi $^{2}$, and Aminullah ${ }^{1 *}$ \\ 1 Department of Food Technology and Nutrition, Faculty of Halal Food Science, Djuanda University, Bogor, West Java, Indonesia \\ 2 Polytechnic of Bogor Chemical Institute, Bogor, West Java, Indonesia \\ *Corresponding email: mardiahrohman@yahoo.com; aminullah@unida.ac.id
}

Submitted: 16 August 2019, Accepted: 22 March 2021, DOI:http://dx.doi.org/10.23960/jtihp.v26i2.65-71

\begin{abstract}
The Roselle petals contain anthocyanin pigment which function as an antioxidant and a natural food colorant. The objective of this research was to study the effect of three enzymes: pectinase, cellulase, and glucoamylase, on the quality of the extract of the Roselle petals. The fresh and dried Roselle petals were extracted using distilled water in a ratio of 1:4, and divided into five parts, in which each part was added by pectinase $(P)$ of 1000ppm; pectinase and cellulase (PC) of 500:500ppm; pectinase and glucoamylase (PG) of 500:500ppm; and pectinase, cellulase and glucoamylase (PCG) of 333:333:333ppm, and without enzyme (TE) as a control. Furthermore, 1\% of citric acid was added to all treatments. Determination of the chosen treatment used was based on residue extract, anthocyanin analysis, and the $\mathrm{pH}$ value. The results showed that fresh Rosella extract with $P C$ has a yield value of $7.60 \%$ and it was not significantly different from the extract with PCG which yielded 7.37\%. Dried Rosella extract with PCG had the highest yield of $22.10 \%$ compared to the control (without enzyme) of $12.96 \%$. However, the PCG addition generated a sticky product. Both fresh and dried Roselle extracts with PC contained the highest anthocyanin content of $156.64 \pm 1.30 \mathrm{mgL}-1$ and $35.09 \pm 0.04 \mathrm{mgL}-1$, respectively. The $\mathrm{pH}$ values of fresh and dried Roselle extracts were 2.65 and 2.24, respectively. This research showed that treatment of fresh and dried Roselle petals with addition of $P, P C$ or PCG increased the extraction yield value. Additionally, these enzymes could also increase the anthocyanin content of the extracts.

Keywords: anthocyanin content; enzyme treatment; extraction yield; $\mathrm{pH}$ value; roselle petal
\end{abstract}

\section{Introduction}

Roselle (Hibiscus sadbariffa Linn) is a member of the Malvaceae family. The Rosella plant thrives well in subtropical and tropical climates and contains a high content of anthocyanin which is a natural red pigment and an antioxidant. Furthermore, Roselle petals contain cyanidin-3-O-glucoside, delphinidin-3O-glucoside, cyanidin-3-O-sambubioside, and delphinidin-3-O-sambubioside (Kouakou et al., 2015). Roselle is very effective in lowering blood pressure and sugar levels (diabetes) (Mardiah et al., 2014; Riaz \& Chopra, 2018; Yusni \& Meutia, 2020), protecting the liver from damage (Halim et al., 2019), enhancing antioxidant enzyme activity in the liver, anti-inflammation, analgesics (Mardiah et al., 2015; Izquierdo-Vega et al., 2020) as well as lowering uric acid (Yuanta, 2019). Roselle petals can be processed into a variety of products such as tea, jam, jelly, juice, natural colorant, and extract powder which can be applied in foods, supplements, and drugs. According to Mardiah et al. (2014), Roselle extract was dried using spray dryers yields lower extraction result. This is due to the residues (pectins) which are normally attached to the walls of the spray dryer that leads to a decline in extraction yield.

Numerous researches have proven that pectinase increases the extract yield of rosella petals (Kumar, 2015; Mardiah et al., 2018). During the extraction of the grape's red pigments, pectin can also shorten the time for macerating, settling, and the filter processes, a lot faster than just using ethanol (Lotfi et al., 2015). According to Hanafi (2009), the combination of both pectinase and cellulase simultaneously, can increase the yield. The enzyme combination has a synergistic effect in increasing the yield of banana juice extraction (Handique et al., 2019) and oil extraction from the pulp of Euterpe oleracea fruit (de Ferreira et 
al., 2018). The aim of the research was to study the synergistic effect of the addition of pectinase, cellulase, and glucoamylase enzymes on the extraction yield of Roselle petals and the quality and content of anthocyanins in the extract.

\section{Materials and methods}

\section{Materials}

The objects of the study were fresh Roselle petals obtained from West Palimanan, Cirebon, Indonesia. Dried Roselle was obtained from drying fresh Rosella under the sun for three days. Pectinase, cellulase, and glucoamylase (Jiangsu Boli Bioproducts Co., Ltd, China), distilled water, citric acid (PT Budi Acid Jaya Tbk., Indonesia), maltodextrin (Shandong Xiwang GroupCo., Ltd, China), and other chemicals were used for this analysis. This research consists of two stages namely; extraction and analysis.

The primary equipment for the research was extraction kits consisted of water bath, stirrer, and thermometer. Other equipments were spray drier, pH meter (WTW, Xylem Inc., Germany), and UV-VIS spectrophotometry (WTW, Xylem Inc., Germany).

\section{Experimentan Design}

The research used a one-factor descriptive statistical analysis method in two replications. Data were analyzed using SPSS ${ }^{\circledR}$ software version 21 (IBM Co., NY, USA). The treatments were the addition of enzymes in the extraction process of fresh and dried Roselle petals. The enzymes added were pectinase (P) of $1000 \mathrm{ppm}$, pectinase and cellulase (PC) of 500:500 ppm, pectinase and glucoamylase (PG) of 500:500 ppm, pectinase, cellulase and glucoamylase (PCG) of 333:333:333 ppm, and without enzyme (TE) as a control

\section{Anthocyanin extraction}

Anthocyanin extraction referred to Mardiah et al. (2014). The anthocyanin extraction was conducted using distilled water in a 1:4 combination ratio of $100 \mathrm{~g}$ of the Roselle petal (fresh or dried) and $400 \mathrm{ml}$ of the distilled water. The enzymes were added according to the treatments, followed by addition of $1 \%$ $(\mathrm{w} / \mathrm{w})$ citric acid to all the treatments. The extraction was conducted at $50^{\circ} \mathrm{C}$ for 60 minutes. The extract was filtered and dried using a spray dryer with $10 \%$ maltodextrin $(\mathrm{w} / \mathrm{w})$ as filler, and inlet and outlet temperatures of $150^{\circ} \mathrm{C}$ and $80^{\circ} \mathrm{C}$ respectively.

\section{Extract Analysis}

The extracted products were analyzed for pH values using a pH meter (WTW, Xylem Inc., Germany) and total anthocyanin content using UV-VIS spectrophotometry (WTW, Xylem Inc., Germany). Anthocyanin content was determined by two replications and quantified in cyaniding 3-glucoside by the following formula:

$$
\begin{aligned}
& \mathrm{A}=[(\mathrm{A} 520-\mathrm{A} 700) \mathrm{pH} 1.0-(\mathrm{A} 520-\mathrm{A} 700) \mathrm{pH} 4.5] \\
& \text { Anthocyanin concentration }(\mathrm{mg} / \mathrm{L})=(\mathrm{A} \times \mathrm{MV} \times \mathrm{DF} \times 1000) /(\varepsilon \times \mathrm{L})
\end{aligned}
$$

A520 is the absorbance of wavelength of $520 \mathrm{~nm}, \mathrm{~A} 700$ is the absorbance of wavelength of $700 \mathrm{~nm}, \mathrm{~A}$ is optional density, MV and $€$ is the molecular weight (449.2) and molar absorbance of cyaniding 3 glucoside, respectively, DF is the dilution factor, $L$ is the cuvette thickness $(\mathrm{cm})$, and $\varepsilon$ is molar absorbance. Measurement of the yield was calculated based on the weight of the Roselle extract after drying and divided by the amount of initial Roselle weight. The amount of sample used was $1 \mathrm{ml}$ of rosella extract. 


\section{Results and discussion}

\section{Extraction yield}

The extraction yield of fresh and dried Roselle petals using several enzymes can be seen in Table 1. Table 1 shows the extraction yield of the fresh roselle petals with the addition of $P, P G, P C$, and PCG, which were $7.60 \%, 6.56 \%, 5.84 \%$, and $7.37 \%$, respectively. Descriptive analysis showed that the extraction yield of Roselle flower petals with the addition of $\mathrm{P}$ were slightly different from the extraction yield from PCG treatment. However, these yields were very different from the extraction yields from the others. Extraction of dried Roselle petals with the addition of PCG resulted in the highest yield of $22.10 \%$, while the yields of extraction with the addition of $\mathrm{P}, \mathrm{PG}$ and $\mathrm{PC}$ were $18.54 \%, 17.3 \%$, and $14.79 \%$, respectively. On the other hand, the extraction yield of dried Roselle flower petals with the addition of PCG was the highest compared the extraction yield from other treatments. Additionally, Table 1 also shows that the addition of pectinase can increase the yield compared to the yield of the control (without enzymes) in the both fresh and dried Rosella treatments. These results were in agreement with Mardiah et al. (2018) which stated that the pectinase enzyme could degrade pectin compounds into simpler forms to increase yield. Pectinase could break pectin bonds in cells and increase procyanidin extract. Other studies (Kumar, 2015; Sudeep et al., 2020; Nguyen and Nguyen, 2018) also explained that pectinase could increase extraction yield, total dissolved solids, and acidity, as well as reduce turbidity and viscosity. Nguyen and Nguyen (2018) stated that pectinase could degrade pectin causing a decrease in the water holding capacity of pectin, which releases more juice in the mixture, and consequently, produces more juice.

Table 1. Extraction yield of fresh and dried Roselle petals

\begin{tabular}{ccc}
\hline \multirow{2}{*}{ Enzyme } & \multicolumn{2}{c}{ Extraction yield (\%) } \\
\cline { 2 - 3 } & Fresh Roselle petals & Dried Roselle petals \\
\hline P & $7.60 \pm 0.35$ & $18.54 \pm 0.45$ \\
PG & $5.84 \pm 0.34$ & $14.79 \pm 0.42$ \\
PCG & $6.56 \pm 0.18$ & $17.30 \pm 0.42$ \\
TE & $7.37 \pm 0.57$ & $22.10 \pm 0.36$ \\
\hline
\end{tabular}

$\mathrm{P}=$ Pectinase; $\mathrm{P}: \mathrm{C}=$ Pectinase $:$ Cellulase; $\mathrm{P}: \mathrm{G}=$ Pectinase $:$ Glucoamylase; $\mathrm{P}: \mathrm{C}: \mathrm{G}$ = Pectinase $:$ Cellulase: Glucoamylase; $\mathrm{T} . \mathrm{E}=$ control (without enzyme).

The combination of PC, PG, and PCG enzymes can increase the yield of both dried and fresh Rosella. The combination of carbohydrase enzymes such as pectinase, pectinesterase, hemicellulase, and cellulase can increase enzyme activity, because the enzymes work synergistically. According to Oumer (2017), the structure of plant cell walls consisted of cellulose, hemicellulose and pectic compounds. Cellulose compounds play a role in giving strength to cell walls, while hemicellulose and pectic compounds function as cementing agents for cellulose tissue. Pectic compounds contribute to complex physiological processes such as cell growth and cell differentiation, including determining the integrity and rigidity of plant tissues. Pectinase can effectively degrade the cell wall structure through the hydrolysis of pectic substances, while cellulase works to reduce the molecular size of cellulose particles and the viscosity of the substrate.

Hanafi (2009) explained that the mechanism of the combination of pectinase and cellulase increased the yield due to their synergistic effect. Cellulase degrades cellulose cell walls while pectinase degrades pectin molecules bound to cellulose compounds. Handique et al. (2019) and de Ferreira et al. (2018) stated that extraction using more than one enzyme produced higher yields.

\section{Anthocyanin content}

The anthocyanin content from fresh and dried Roselle petals can be seen in Table 2. Table 2 shows that the fresh Rosella extract contains more anthocyanins than the dried rosella extract. This was due to the high temperature applied to the drying process of dried Rosella flower petals reduced anthocyanin content 
(Mardiah et al., 2015). Further analysis showed that the anthocyanin content of all enzyme treatments tent to be higher than that of the non-enzyme (TE) treatment. The lowest anthocyanin content was produced from fresh Roselle flower petals with pectinase (P) treatment. According to Vukoja et al. (2019), pectinase reduced the stability of anthocyanins due to its glucosidase activity which hydrolyzed the glycoside bonds of $\beta-1-2$ cyanidin-3-sophoroside and cyanidin-3-glucosyl-rutinoside to cyanidin-3-glycoside and cyanidin3-rutinoside. Furthermore, extraction with the addition of pectinase and cellulase (PC) resulted in the highest anthocyanin content in both fresh and dried Roselle extracts. According to Lotfi et al. (2015) pectinase and cellulase had a synergistic effect in breaking down the cell wall and so that the anthocyanin pigments in the cell wall were easily extracted. The same thing was also expressed by Ranveer et al. (2020), that the addition of cellulase and pectinase enzymes increased the concentration of anthocyanins in the skin of kokum fruit (Garcinia indica Choisy). Jia et al. (2019) also informed that the combined use of cellulose, hemicellulose, and pectinase enzymes increased anthocyanin content, shortened processing time, increased efficiency, and lowered processing temperatures in the manufacture of cherry wine compared to using single enzymes. This happens because hemicellulase enzymes break down cellulases and hemicellulases, dissolving plant cell walls and releasing more intracellular solutions. In contrast, lower anthocyanin content was obtained when glucoamylase was added (PG and PCG) to the treatment. This happens because glucoamylase degrade anthocyanin pigments and make them unstable by hydrolyzing the bonds between aglycones and glycones. The hydrolysis causes the aromatic ring of anthocyanins to turn into colorless cation compounds.

Table 2. Anthocyanin content of fresh and dried Roselle petals

\begin{tabular}{ccc}
\hline \multirow{2}{*}{ Enzyme } & \multicolumn{2}{c}{ Anthocyanin content $\left(\mathrm{mg}^{-1}\right)$} \\
\cline { 2 - 3 } & Fresh Roselle petals & Dried Roselle petals \\
\hline PC & $101.29 \pm 0.53$ & $26.40 \pm 0.46$ \\
PG & $184.02 \pm 0.15$ & $35.09 \pm 0.04$ \\
PCG & $156.64 \pm 1.30$ & $33.20 \pm 0.80$ \\
TE & $141.05 \pm 0.56$ & $23.51 \pm 0.53$ \\
\hline
\end{tabular}

$\mathrm{P}=$ Pectinase; $\mathrm{P}: \mathrm{C}=$ Pectinase $:$ Cellulase; $\mathrm{P}: \mathrm{G}=$ Pectinase $:$ Glucoamylase; $\mathrm{P}: \mathrm{C}: \mathrm{G}=$ Pectinase $:$ Cellulase: Glucoamylase; $\mathrm{T} . \mathrm{E}=$ control (without enzyme).

Glucoamylase can increase the sugar content in the extract. The presence of sugar induces an increase in the color intensity of anthocyanins under acidic conditions. However, the higher sugar content in the extraction led to lower anthocyanin stability. The presence of sugar can accelerate the degradation of anthocyanins and their ability to condense with anthocyanins and produce brown compounds. Glucoamylase could hydrolyze $a-1,6$ glycosidic bonds so that the dextrin product would be converted into glucose units, the dextrin product caused a high level of sweetness and sugar yield (Tiwari et al., 2015). Additionally, the extraction treatment with addition of PCG resulted in a sticky extract caused by high glucose levels. Kumar (2015) also reported that glucoamylase reacts with carbohydrates to produce a sticky extract.

\section{pH value}

The $\mathrm{pH}$ value of fresh and dried Roselle petals can be seen in Table 2. Table 3 shows that the $\mathrm{pH}$ values of all treatments in the range of 2.3-2.7, which means the $\mathrm{pH}$ value of Roselle flower petal extract is stable. The addition of enzymes to fresh or dried Roselle petals did not affect the $\mathrm{pH}$ value. In addition, further analysis showed that all combinations of enzyme additions had no effect on the $\mathrm{pH}$ value of fresh Roselle petal extract. However, the combination of enzyme additions effected the $\mathrm{pH}$ of the dried Roselle flower petal extract. This $\mathrm{pH}$ condition also indicated the optimum working conditions for the enzyme, where pectinase had an optimum pH of 5.8 (Sudeep et al., 2020). Li et al. (2020) reported that the best pH to produce the most anthocyanins in Mulberry juice extract using pectinase was in the $\mathrm{pH}$ range of 3-6. At a 
higher $\mathrm{pH}$, pectinase had a lower ability to decompose cell walls, resulted in lower anthocyanins being extracted.

Table 3. $\mathrm{pH}$ value of fresh and dried Roselle petals

\begin{tabular}{ccc}
\hline \multirow{2}{*}{ Enzyme } & \multicolumn{2}{c}{$\mathrm{pH}$} \\
\cline { 2 - 3 } & Fresh Roselle petals & Dried Roselle petals \\
\hline P & $2.56 \pm 0.10$ & $2.79 \pm 0.04$ \\
PC & $2.74 \pm 0.33$ & $2.46 \pm 0.09$ \\
PCG & $2.38 \pm 0.09$ & $2.21 \pm 0.13$ \\
TE & $2.65 \pm 0.07$ & $2.24 \pm 0.28$ \\
\hline
\end{tabular}

$P=$ Pectinase $P: C=$ Pectinase $:$ Cellulase; $P: G=$ Pectinase $:$ Glucoamylase; $P: C: G=$ Pectinase $:$ Cellulase: Glucoamylase; $T . E=$ control (without enzyme).

Anthocyanin stability was influenced by several factors, one of which was the $\mathrm{pH}$ value. The low $\mathrm{pH}$ value of 2-4 affected the stability of anthocyanins because under these conditions anthocyanins were reddish in color and were in the form of cyanidin-3 glucoside and cyanid-3 on the outside. A decrease in pH would shift the equilibrium condition to the red flavilium cation. Conversely, an increase in $\mathrm{pH}$ would form carbinol and colorless balconies (Nurtiana, 2019). Khoo et al. (2017) reported that $\beta$ glucosidase enzymes caused anthocyanin color changes to become anthocyanidins and sugars that spontaneously formed colorless aglycones (anthocyanidins). The $\mathrm{pH}$ measurement showed that the cyanidin content was more stable at pH below 3 (Lotfi et al., 2015), and Jia et al. (2019) stated that at pH 3, the anthocyanin extract reached its maximum value. There was an effect of $\mathrm{pH}$ on the color change of anthocyanins, where a $\mathrm{pH}$ of less than 3 could control the color change that correlates with the anthocyanin content in red sweet fermented drinks (Khoo et al., 2017). The addition of acids such as citric acid and lactic acid prevents the breakdown of anthocyanins. In this reseach, $1 \%$ citric acid was added to all Roselle flower petal extraction treatments to maintain the $\mathrm{pH}$ below 3 , so that the color of Roselle extract powder was in excellent stability. Lotfi et al. (2015) reported the color of anthocyanin extracts produced using solvents with the addition of enzymes (pectinase, cellulose, proteases) resulted in better chroma values and more stable lightness than those produced from acidified ethanol solvents.

\section{Conclusion}

The data in this work confirmed that the addition of PCG enzymes increased the extraction yield on both fresh and dried Roselle petals, followed by the addition of P, PG and PC, however, PCG produced a sticky extract. The highest anthocyanin level was obtained from the extract with the addition of PC on both fresh and dried Roselle petals. The addition of enzymes on fresh or dried Roselle petals did not affect the range of $\mathrm{pH}$ value (2.3-2.7).

\section{Acknowledgements}

This research was supported by Grant of Penelitian Unggulan Perguruan Tinggi (PUPT) under contract No.1598/K4/KM/2017 from Ministry of Research, Technology, and Higher Education, Republic of Indonesia.

\section{References}

de Ferreira, E. S., Rogez, H. L. G., \& Herman, C. A. N. P. (2018). Effect of the combination of enzymatic preparations on the aqueous extraction yield of the oil from the pulp of Euterpe oleracea fruit. Brazilian Journal of Chemical Engineering, 35(4), 1193-1201. https://doi.org/10.1590/01046632.20180354s20170305

Halim, D., Sihning, E. J., \& Tehupuring. (2019). The effect of roselle (Hibiscus sabdariffa Linn) flower extract to the SGPT activity in male wistar rats (Rattus norvegicus) induced by high dose paracetamol. IOP 
Conference Series: Earth and Environmental Science, 217(1). https://doi.org/10.1088/1755$1315 / 217 / 1 / 012018$

Hanafi. (2009). Sifat aktivitas enzim sellulase dan pectinase dalam mendegradasi dinding sel tanaman untuk tujuan ekstraksi pigmen. Akademi Kimia Analis.

Handique, J., Bora, S. J., \& Sit, N. (2019). Optimization of banana juice extraction using combination of enzymes. Journal of Food Science and Technology, 56(8), 3732-3743. https://doi.org/10.1007/s13197-019-03845-z

Izquierdo-Vega, J. A., Arteaga-Badillo, D. A., Sánchez-Gutiérrez, M., Morales-González, J. A., VargasMendoza, N., Gómez-Aldapa, C. A., Castro-Rosas, J., Delgado-Olivares, L., Madrigal-Bujaidar, E., \& Madrigal-Santillán, E. (2020). Organic acids from Roselle (Hibiscus sabdariffa L.)-A brief review of its pharmacological effects. Biomedicines, 8(5), 1-16. https://doi.org/10.3390/BIOMEDICINES8050100

Jia, C., Han, F., Miao, X., Zhang, Q., Yan, A., \& Wu, P. (2019). Study on optimization of extraction process of anthocyanin from cherry wine lees. 9(1), 18-27. https://doi.org/10.15406/jnhfe.2019.09.00321

Khoo, H. E., Azlan, A., Tang, S. T., \& Lim, S. M. (2017). Anthocyanidins and anthocyanins: Colored pigments as food, pharmaceutical ingredients, and the potential health benefits. Food and Nutrition Research, 61, 1-21. https://doi.org/10.1080/16546628.2017.1361779

Kouakou, T. H., Konkon, N. G., Ayolié, K., Obouayeba, A. P., Abeda, Z. H., \& Koné, M. (2015). Anthocyanin production in calyx and callus of Roselle (Hibiscus sabdariffa L.) and its impact on antioxidant activity. Journal of Pharmacognosy and Phytochemistry JPP, 4(43), 9-15. http://www.phytojournal.com/archives/2015/vol4issue3/PartA/4-3-24.1.pdf

Kumar, S. (2015). Role of enzymes in fruit juice processing and its quality enhancement. Advances in Applied Science Research, 6(6), 114-124.

Li, Y., Tao, F., Wang, Y., Cui, K., Cao, J., Cui, C., Nan, L., Li, Y., Yang, J., \& Wang, Z. (2020). Process optimization for enzymatic assisted extraction of anthocyanins from the mulberry wine residue. IOP Conference Series: Earth and Environmental Science, 559, 012011. https://doi.org/10.1088/1755$1315 / 559 / 1 / 012011$

Lotfi, L., Kalbasi-Ashtari, A., Hamedi, M., \& Ghorbani, F. (2015). Effects of enzymatic extraction on anthocyanins yield of saffron tepals (Crocos sativus) along with its color properties and structural stability. Journal of Food and Drug Analysis, 23(2), 210-218. https://doi.org/10.1016/j.jfda.2014.10.011

Mardiah, Hasanah, R. N., Novidahlia, N., \& Hasan, A. E. Z. (2018). Optimasi kondisi ekstraksi menggunakan enzim dengan response surface methodology (RSM) terhadap ekstrak kelopak bunga rosela (Hibiscus sabdariffa L). Jurnal Pertanian, 9(2), 93-100.

Mardiah, Zakaria, F. R., Prangdimurti, E., \& Damanik, R. (2014). The effect of roselle extract (Hibiscus sabdariffa Linn.) on blood glucose level and total antioxidant level on diabetic rat induced by streptozotocin. IOSR Journal of Pharmacy, 4(10), 08-16. https://doi.org/10.9790/3013-0401008016

Mardiah, Zakaria, F. R., Prangdimurti, E., \& Damanik, R. (2015). Anti-inflammatory of purple Roselle extract in diabetic rats induced by streptozotocin. Procedia Food Science, 3, 182-189. https://doi.org/10.1016/j.profoo.2015.01.020

Nguyen, C. L., \& Nguyen, H. V. N. (2018). The Quality of Mulberry Juice as Affected by Enzyme Treatments. Beverages, 4(41), 1-12. https://doi.org/10.3390/beverages4020041

Nurtiana, W. (2019). Anthocyanin as natural colorant: a review. Food ScienTech Journal, 1(1), 1-7. https://doi.org/10.33512/fsj.v1i1.6180

Oumer, O. J. (2017). Pectinase: substrate, production and their biotechnological applications. International Journal of Environment, Agriculture and Biotechnology, 2(3), 1007-1014. https://doi.org/10.22161/ijeab/2.3.1

Ranveer, R. C., Nanadane, A. S., Ganorkar, P. M., \& Sahoo, A. K. (2020). Enzyme-assisted extraction of anthocyanin from kokum (Garcinia indica Choisy) rinds. European Journal of Nutrition \& Food Safety, 12(10), 125-133. https://doi.org/10.9734/ejnfs/2020/v12i1030309

Riaz, G., \& Chopra, R. (2018). A review on phytochemistry and therapeutic uses of Hibiscus sabdariffa L. Biomedicine and Pharmacotherapy, 102, 575-586. https://doi.org/10.1016/j.biopha.2018.03.023

Sudeep, K. C., Upadhyaya, J., Joshi, D. R., Lekhak, B., Chaudhary, D. K., Pant, B. R., Bajgai, T. R., Dhital, R., Khanal, S., Koirala, N., \& Raghavan, V. (2020). Production, characterization, and industrial application of pectinase enzyme isolated from fungal strains. Fermentation, 6(59), 1-10. 
https://doi.org/10.3390/FERMENTATION6020059

Tiwari, S. P., Srivastava, R., Singh, C. S., Shukla, K., Singh, R. K., Singh, P., Singh, R., Singh, N. L., \& Sharma, R. (2015). Amylases: an overview with special reference to alpha amylase. Journal of Global Biosciences, 4(1), 1886-1901.

Vukoja, J., Pichler, A., \& Kopjar, M. (2019). Stability of anthocyanins, phenolics and color of tart cherry jams. Foods, 8(7), 1-9. https://doi.org/10.3390/foods8070255

Yuanta, Y. (2019). Pengaruh pemberian seduhan rosella terhadap penurunan kadar asam urat wanita menopause. ARTERI : Jurnal IImu Kesehatan, 1(1), 69-75. https://doi.org/10.37148/arteri.v1i1.23

Yusni, Y., \& Meutia, F. (2020). Action mechanism of rosella (Hibiscus sabdariffa L.) used to treat metabolic syndrome in elderly women. Evidence-Based Complementary and Alternative Medicine, 2020, 1-6. https://doi.org/10.1155/2020/5351318 